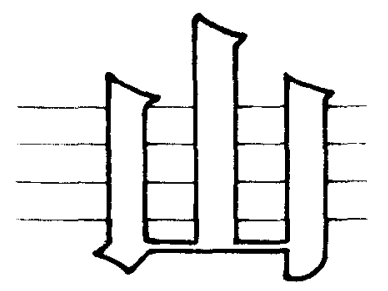

\title{
DEVONIAN SERIES BOUNDARIES: Decisions of the IUGS Subcommission
}

\author{
by Willi Ziegler and Gilbert Klapper
}

\begin{abstract}
The Commission on Stratigraphy is by far the largest in IUGS, with Subcommissions, Working Groups and Regional Committees studying all the major intervals and boundaries in the geological column. As an example of how its Subcommissions may progress towards the definition of boundary stratotypes, the authors present here an account of the debates and voting procedures which have led recently to agreement on two important boundaries within the Devonian.
\end{abstract}

-Editor

The IUGS Subcommission on Devonian Stratigraphy was organized at a meeting in Marburg, F.R.G. in December 1973. The consensus of this and all subsequent meetings was to give highest priority to the resolution of the controversies surrounding the Lower-Middle Devonian and Middle-Upper Devonian Series Boundaries. Members also agreed to follow the procedure established by the Silurian-Devonian Boundary Committee (summarized by McLaren, 1977) in first deciding on a critical biostratigraphic level and subsequently selecting a corresponding boundary stratotype at which to define the series boundary. Guidelines for the selection of seriesboundary stratotypes were unanimously adopted at the 1975 Subcommission meeting in Morocco.

Since 1974 intensive annual discussion meetings have been held by the Subcommission together with field trips, except for 1980 (Zeigler and Klapper, 1982a). As a result of these activities and in response to the need for more refined information on stratigraphic correlation at the levels under consideration, a number of significant results of research have been published, enabling the Subcommission to reach the decisions discussed here.

\section{The Lower-Middle Devonian Series Boundary}

At the 1979 meeting in Sigüenza, Spain, the discussion on the Lower-Middle Devonian boundary focused on two biostratigraphic levels: the lower boundaries of the patulus conodont Zone and the partitus conodont Zone (hereafter referred to as the patulus and partitus boundaries). The former level corresponds essentially to the base of the Couvinian Stage in the Ardennes, southern Belgium, and the latter almost exactly to the base of the Eifelian Stage (Heisdorf-Lauch boundary) in the Eifel Mountains, F.R.G. (See Fig. 1). Two other levels in the conodont sequence that had been considered at previous meetings (the base of the dehiscens Zone, corresponding to the boundary favoured within the Soviet Union, and the base of the costatus costatus Zone, corresponding to the basal Chotec boundary in the Barrandian area of Czechoslovakia) were eliminated as a consequence of a vote in 1979.

The Devonian Subcommission, like those dealing with other systems, includes both titular members who have voting rights and corresponding members who do not. At Sigüenza an informal ballot led to seven votes plus two postal ballots cast for the partitus boundary and three plus one postal vote for the patulus boundary; there was one abstention. In order to inform titular members, corresponding members were also asked to vote and did so seven to two in favour of the partitus boundary. Then in 1980 a formal postal vote resulted in eleven for partitus, three for patulus and one abstention, with corresponding members voting 11 for partitus, four for patulus and two abstentions.

Potential boundary stratotypes for the partitus boundary were discussed in 1979 and 1980, and formal proposals were received at the Binghamton, New York, meeting in July 1981 , from the Federal Republic of Germany (Werner and Ziegler,

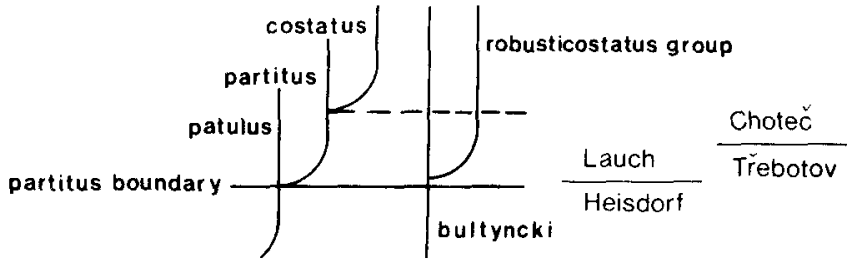

Figure 1. The relationship of the Lower-Middle Devonian Boundary (the partitus boundary) to the phvletic lineage from Polygnathus costatus patulus to $P$. c. costatus, to the lineage from $P$. linguiformis bultyncki to the $P$. robusticostatus group (sensu Weddige and Ziegler), and to the Heisdorf-Lauch and Trebotov-Chotec boundaries (From Ziegler and Klapper, 1982a).

1982) and from Ivo Chlupác of the Geological Survey of Czechoslovakia (Chlupáč, 1982,). By a vote of nine to four with two abstentions, the Wetteldorf Richtschnitt (Prüm Syncline, Eifel Mountains) was chosen as the holostratotype section for the Lower-Middle Devonian boundary (Fig. 2) and the Holyne Prastav Quarry (Barrandian area) as the parastratotype. The base of the partitus Zone is $1.90 \mathrm{~m}$ below the Heisdorf-Lauch boundary at the Wetteldorf Richtschnitt, which had been established by Rudolf Richter and his coworkers in the 1930s (Fig. 3).

At Binghamton an additional resolution, passed with one abstention, states that the base of the Middle Devonian Series will coincide exactly with the base of the lower stage of the Middle Devonian (name unspecified in this vote). A third resolution passed unanimously at the Binghamton meeting contains the statement that the Subcommission accepts Eifelian and Givetian at the stage names for the Middle Devonian and the Frasnian and the Famennian as the stage names for the Upper Devonian.

The result of these resolutions requires that the lower boundary of the type Eifelian (previously equivalent to the base of the Lauch Formation) be adjusted downward $1.90 \mathrm{~m}$ into the upper part of the Heisdorf Formation in the Wetteldorf Richtschnitt to coincide exactly with the Series boundary at the lower limit of the partitus Zone (see Weddige et al., 1979; and Weddige, 1982).

Figure 2 (opposite): Locality map of site of the boundary stratotype of the partitus-boundary at the Wetteldorf Richtschnitt. Upper right is columnar section of stratotype showing distribution of conodonts in marl/imestone alteration. Horo I to III and Libra I are bentonite layers. The HeisdorfLauch Formation junction is the previously used LowerMiddle Devonian boundary (from Werner and Ziegler, 1982). 

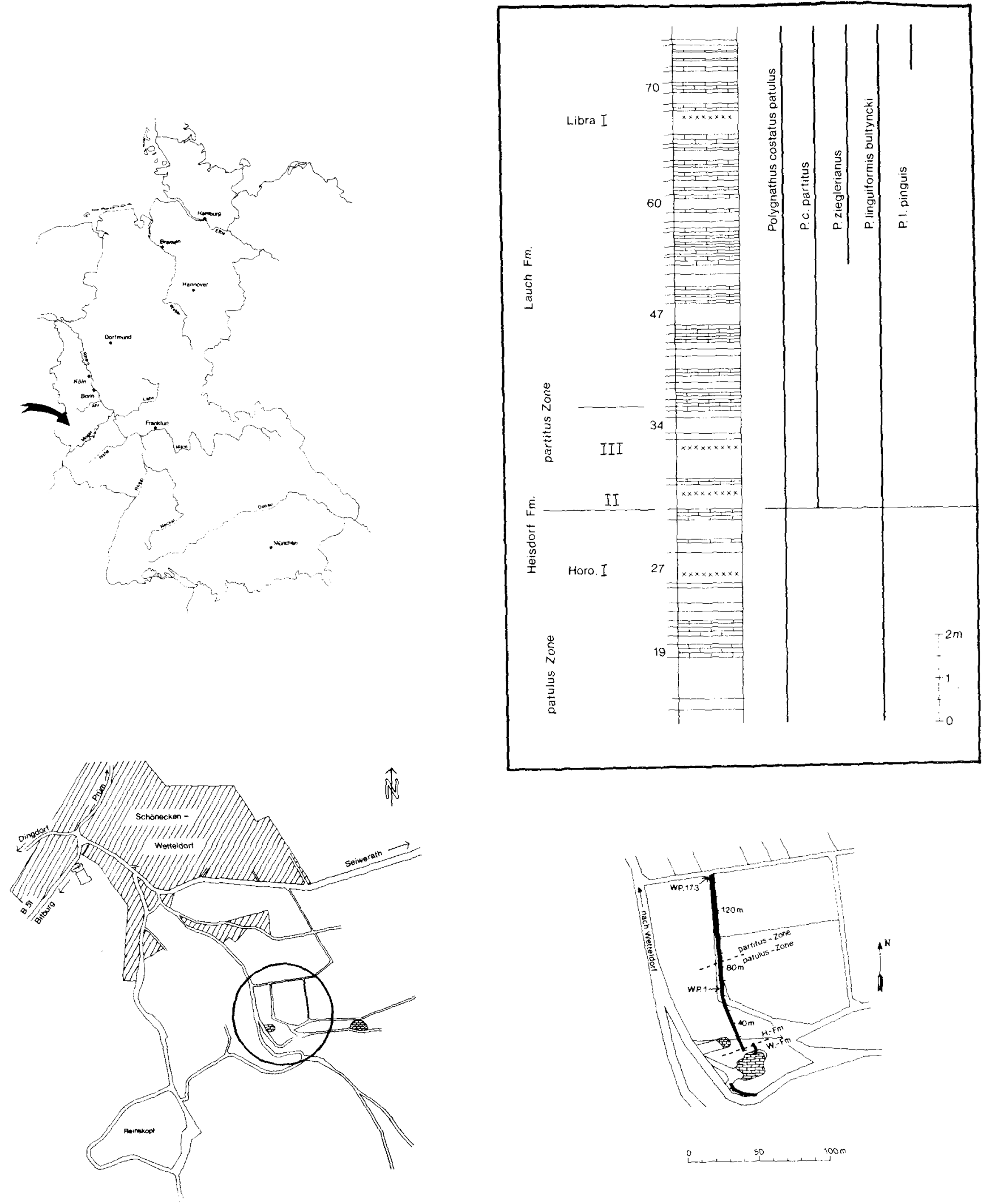

EPISODES, Vol. 1982, No. 4. 


\section{The Middle-Upper Devonian Series Boundary}

At Sigüenza in 1979 the discussion of potential biostratigraphic levels for this boundary (Fig. 4) concentrated on:

- level 1 - entry of Pharciceras amplexum (ammonoid)

- level 2 - a range of stratigraphy extending from the entry of multilobate Pharciceras species (including P. lunulicosta) up to the entry of Palmatolepis disparilis (conodont) and the first Ponticeras (ammonoid; for the disparilis Zone see Ziegler and Klapper, 1982b),

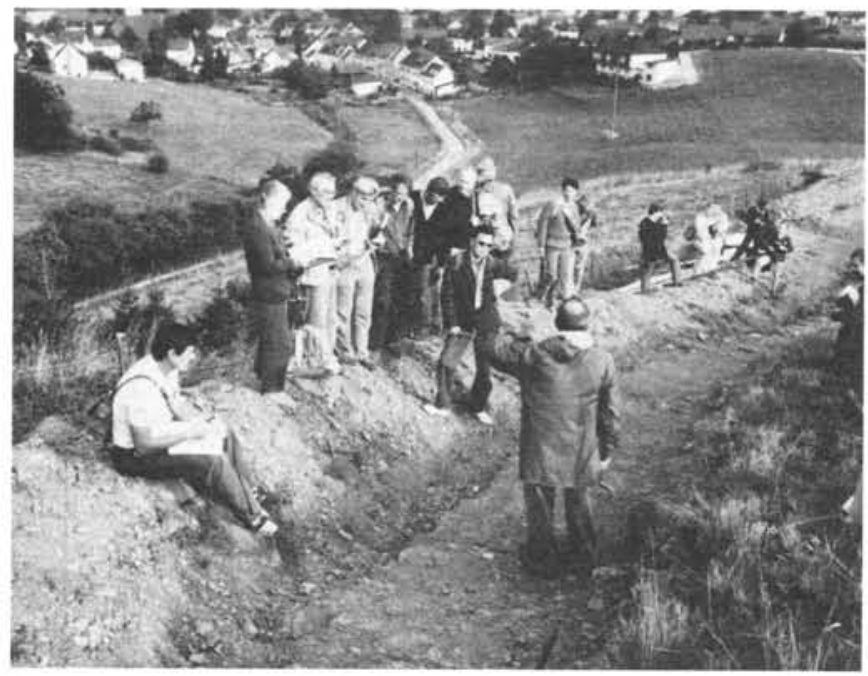

Figure 3: The Subcommission on the Devonian examines the stratotype for the Lower-Middle Devonian Series Boundary at Prïm, Wetteldorf Richtschnitt, in August 1982. The trench was initially dug in the 1930s to enable a study of the sequence and meafauna and reopened in the 1970 s to allow an examination of conodonts and other fossils. It was then filled in to protect the section from amateur collectors and reopened once again in 1982 for the Subcommission's visit. Plans are for a permanent building to be erected over the key portion of the trench allowing access only to bona fide researchers.

\begin{tabular}{|c|c|c|c|}
\hline \multicolumn{3}{|c|}{ Conodont Zonation } & Ammonoid Faunas \\
\hline \multirow{6}{*}{ asymmetricus Zone } & Previous & Present & \multirow{5}{*}{$\begin{array}{l}\text { Manticoceras cordatum } \\
\text { Belgium, W.Germany } \\
?\end{array}$} \\
\hline & Upper Zone & Upper Zune & \\
\hline & Middle Zone & Middle Zone & \\
\hline & Lower Zone & Lower Zone & \\
\hline & \multirow{2}{*}{ Lowermost Zone } & Lowermost Zone & \\
\hline & & dispartilis Zone & $\begin{array}{l}\text { Ponticeras pernai } \\
\text { Morocco, W.Germany }\end{array}$ \\
\hline \multirow[t]{2}{*}{ hermanni-cristatus Zone } & Upper Subzone & Upper Subzone & \multirow{2}{*}{$\begin{array}{l}\text { multilobate Phärciceras } \\
\text { Morocco }\end{array}$} \\
\hline & Lower-Subzone & Lower Subzone & \\
\hline \multirow{2}{*}{ varcus Zone } & Upper Subzone & Upper Subzone & \\
\hline & Middle Subzone & Middle Subzone & $\begin{array}{l}\text { Pharciceras amplexum (New York, Morocco) } \\
\text { Maenioceras terebratum } \\
\text { (Morocco, W. Germany) }\end{array}$ \\
\hline
\end{tabular}

Figure 4: Diagram showing the stratigraphic relationship between conodont zonation and ammonoid faunas (from Ziegler \& Klapper, 1982b). The three original candidate levels for the Middle-Upper Devonian Series Boundary are also shown: 1) Pharciceras amplexum level, 2) ranqe of stratigraphy from multilobate Pharciceras species up to the first Ponticeras species and the entry of the disparilis Zone, 3), the base of the Lower asymmetricus Zone. The latter was selected as the Middle-Upper Devonian boundary level.
- level 3 - the base of the Lower asymmetricus conodont Zone (Ziegler 1971; and Bultynck, 1982).

An informal vote taken showed six titular members for level 2, three for level 3 and none for level 1 .

In 1981, new analyses of European material and new collections from Morocco showed that the entry of multilobate Pharciceras species occurs in the Upper hermanni-cristatus conodont Subzone, and that the entries of Palmatolepis disparilis and early Ponticeras species coincide. Pharciceras aff. P. amplexum was found in Morocco to coincide with the entry of Ozarkodina semialternans (conodont), occurring in the uppermost part of the Middle varcus Subzone as P. amplexum does in the Tully Limestone of New York.

Discussion at the 1979-1981 meetings indicated that level 1 corresponds essentially to the basal Upper Devonian boundary widely agreed upon by participants at the International Geological Congresses toward the end of the last century (House, 1982). Level 2 is very close to the base of the Upper Devonian as used by ammonoid workers in Germany since the time of Denckmann in 1900 (see House and Ziegler, 1977), and according to P. Sartenaer (Belgium), level 3 corresponds almost exactly to the base of the Frasnian, the lower stage of the Upper Devonian.

In Binghamton a vote was considered to adopt the base of the Lower asymmetricus Zone (level 3 ) as the biostratigraphic level for the Middle-Upper Devonian Series boundary, but the members were still divided. Likewise, after extensive discussion at the Frankfurt meeting in August, 1982, a vote to accept the base of the disparilis Zone (Ziegler and Klapper, 1982b) as the level for the Middle-Upper Devonian Series boundary was split. However a motion to accept the base of the Lower asymmetricus Zone as the level for the boundary gained the support of seven members with three against, and one abstention. In a subsequent discussion, the minority against the Lower asymmetricus boundary agreed to support the majority, provided that the latter would in turn agree that the boundary stratotype be located in the pelagic facies. Thus, a motion that the base of the Lower asymmetricus Zone be accepted as the biostratigraphic level for the Middle-Upper Devonian boundary resulted in ten votes for the motion, none against, and one abstention. Corresponding members were eight for, none against, with four abstentions. A second motion stating that the boundary holostratotype be located in the pelagic facies and the parastratotype in the neritic facies was adopted unanimously by both titular and corresponding members.

In view of this progress, we fully expect that a definitive boundary stratotype will be selected at the 1983 meeting of the Subcommission. The results of all decisions will then be presented to the International Commission on Stratigraphy which meets next at the 1984 International Geological Congress in Moscow.

\section{References}

Bultynck, P., 1982. The Ancyrodella binodosa - A. rotundiloba rotundiloba transition, a datum level for correlation of the Givetian-Frasnian boundary. In: Papers on the Frasnian-Givetian boundary, Bigey, F. $\overline{\text { et }}$ al., Geol. Surv. Belgium, 17-33, Brussels.

Chlupáč. I., 1982. Preliminary submission for Lower-Middle Devonian Boundary Stratotype in the Barrandian area. Cour. Forsch.-Inst. Senckenberg, v. 55, p. 85-96.

House M.R., 1982. The Middle-Upper Devonian Series Boundary and decisions of the International Geological Congress. Cour. Forsch. Inst. Senckenberg, v. 55, p. 449-462.

House, M.R. and Ziegler, W., 1977. The goniatite and conodont sequences in the early Upper Devonian at Adorf, Germany. Geol. et Palaeont., v. 11, p. 69-108. 
McLaren, D.J., 1977. The Silurian-Devonian Boundary Committee, A final report. In: The Silurian-Devonian Boundary, Martinsson, A. (ed.), Int. Union of Geol. Sci. Ser. A, No. 5, p. 1-34, Stuttgart.

Weddige, K., 1982. The Wetteldorf Richtschnitt as boundary stratotype from the view point of conodont stratigraphy. In: Proposal of a boundary stratotype for the LowerMiddle Devonian Boundary (partitus-Boundary), Werner, R. and Ziegler, W. (eds.), Cour. Forsch.-Inst. Senckenberg, v. 55, p. 26-37.

Weddige, K., Werner, R. and Ziegler, W., 1979. The EmsianEifelian Boundary; An attempt at correlation between the Eifel and Ardennes Regions. Newsl. Stratigr., v. 8, p. 159169.

Werner, R. and Ziegler, W. (eds.), 1982. Proposal of a boundary stratotype for the Lower/Middle Devonian Boundary (partitus-Boundary). In: Ziegler, W. and Werner, R. (eds.), On Devonian Stratigraphy and Palaeontology of the Ardenno-Rhenish Mountains and Related Devonian Matters, Cour. Forsch.-Inst. Senckenberg, v. 55, p. 13-84.

Ziegler, W., 1971. Conodont stratigraphy of the European Devonian. In: Symposium on conodont biostratigraphy, Sweet, W.C. and Bergström, S.M. (eds.), Geol. Soc. America Memoir, v. 127, p. 227-284.

Ziegler, W. and Klapper, G., 1982a. Subcommission on Devonian Stratigraphy: Decisions since 1973 and present status. Cour. Forsch.-Inst. Senckenberg, v. 55, p. 7-12.

Ziegler, W. and Klapper, G., 1982b. The disparilis conodont zone, the proposed level for the Middle-Upper Devonian boundary. Cour. Forsch.-Inst. Senckenberg, v. 55, p. 463492.

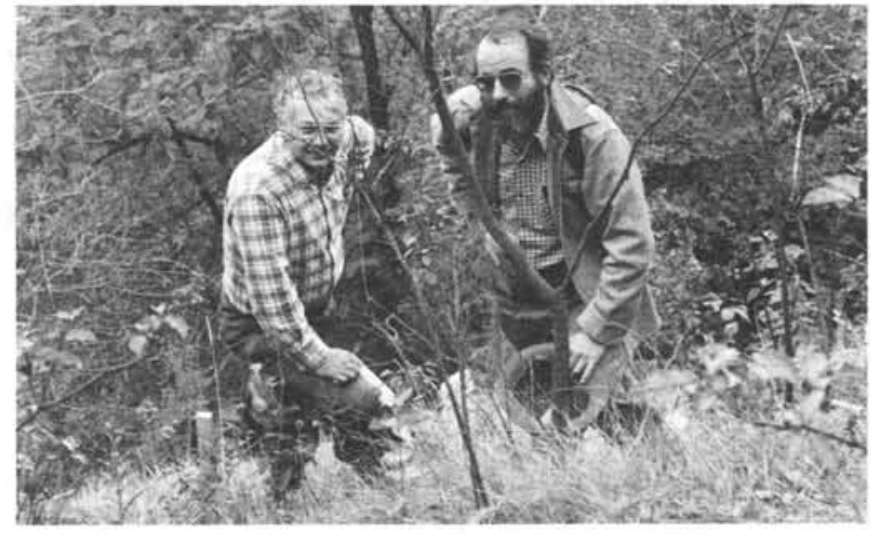

\section{ABOUT THE AUTHORS:}

Prof. Dr. Willi Ziegler (left) is Director of the Senckenberg Research Institute and Natural History Museum, 600 Frankfurt 1, F.R.G., and Professor of Palaeontology and Geology at the University of Marburg. His research interests center mainly around Upper Palaeozoic stratigraphy and concentrate on the Devonian and its conodont biostratigraphy and palaeontology. As the Secretary (1973-1976) and Chairman since 1976 of the IUGS Subcommission on Devonian Stratigraphy, he has examined most relevant sections of Devonian rocks throughout the world.

Dr. Gilbert Klapper (right) is Professor of Geology and the University of Iowa, Iowa City, Iowa 52242, U.S.A. His research concentrates on Silurian and Devonian conodont taxonomy and biostratigraphy. He has been Vice Chairman of the Devonian Subcommission since 1976.

\section{LIST OF ABBREVIATIONS}

(aside from those identified in the text or in Directory of IUGS Bodies)

AAPG
ASCE
ASEAN
BRGM
CCOP
CNRS
CSIRO
CSPG
ESCAP
GSC
IAEA
IAHR
IAHS
IAMAP
ICSOBA
IDRC
IHP
ILP
IMM
ISSMFE
IUTAM
NATO
NOAA
SEPM
UNESCO
WEDC

American Association of Petroleum Geologists

American Society of Civil Engineers

Association of South East Asian Nations

Bureau de Recherches Géologiques et Minières (France)

ESCAP Committee for Co-ordination of Joint Prospecting for

Mineral Resources in Asian Offshore Areas

Centre National de la Recherche Scientifique (France)

Commonwealth Scientific and Industrial Research Organization

(Australia)

Canadian Society of Petroleum Geologists

UN Economic and Social Commission for Asia and the Pacific

Geological Survey of Canada

International Atomic Energy Agency

International Association for Hydraulic Research

International Association of Hydrological Sciences

International Association of Meteorology and Atmospheric Physics

International Committee for the Study of Bauxites, Alumina and

Aluminum

International Development Research Centre (Canada)

International Hydrological Programme

ICSU/IUGS/IUGG International Lithosphere Program

Institute of Mining and Metallurgy (UK)

International Society for Soil Mechanics and Foundation Engineering

International Union of Theoretical and Applied Mechanics

North Atlantic Treaty Organization

National Oceanographic and Atmospheric Administration (U.S.A.)

Society of Economic Paleontologists and Mineralogists

UN Educational, Scientific and Cultural Organization

Water and Waste Engineering for Developing Countries (Loughborough

University of Technology, U.K.) 